\title{
O POVO TICUNA SOB UMA PERSPECTIVA HISTÓRICA: DE SUAS ORIGENS MITOLÓGICAS À PERDA DE SUA IDENTIDADE ${ }^{1}$
}

\author{
EL PUEBLO TICUNA DESDE UNA PERSPECTIVA HISTÓRICA: DE SUS ORÍGENES \\ MITOLÓGICOS A LA PÉRDIDA DE SU IDENTIDAD
}

\begin{abstract}
THE TICUNA PEOPLE FROM A HISTORICAL PERSPECTIVE: FROM THEIR MYTHOLOGICAL ORIGINS TO THE LOSS OF THEIR IDENTITY
\end{abstract}

\author{
Eli Leão CATACHUNGA ${ }^{2}$ \\ Rosana Maria Pires Barbato SCHWARTZ ${ }^{3}$ \\ Renan Antônio da SILVA ${ }^{4}$
}

RESUMO: Os povos indígenas têm se mantido únicos devido às suas estratégias sociais e culturais, e as atividades educacionais são uma delas. A educação realizada pelos povos indígenas permite que eles continuem a sobreviver e evitem que sua cultura seja transmitida de geração em geração. O povo Ticuna teve longa trajetória no decorrer de sua história, ora marcada pela profunda estabilidade (das origens mitológicas ao primeiro contato com o povo não-indígena), ora marcada por uma profunda violência simbólica e física que ocasionou na perda e da negação de certos aspectos indenitários (a partir do primeiro contato). Veremos algumas das consequências desse contato, que por vezes permanecem até os dias atuais.

PALAVRAS-CHAVE: Contato. Ticuna. Não-indígena. Cosmovisão. Violência.

RESUMEN: Los pueblos indigenas se han mantenido únicos por sus estrategias sociales y culturales, y las actividades educativas son una de ellas. La educación que realizan los pueblos indígenas les permite seguir sobreviviendo y evitar que su cultura se transmita de generación en generación. El pueblo ticuna ha tenido una larga trayectoria a lo largo de su historia, en momentos marcada por una profunda estabilidad (desde los orígenes mitológicos hasta el primer contacto con los no indígenas), en ocasiones marcada por una profunda violencia simbólica y física que llevó a la pérdida y negación de ciertos aspectos de indemnización (desde el primer contacto). Veremos algunas de las consecuencias de este contacto, que en ocasiones se mantienen hasta el día de hoy.

PALABRAS CLAVE: Contacto. Ticuna. No indígena. Cosmovisión. Violencia.

\footnotetext{
${ }^{1}$ Este artigo retrabalha, com novos dados, trechos de minha dissertação de mestrado.

${ }^{2}$ Universidade Presbiteriana Mackenzie (MACKENZIE), São Paulo - SP - Brasil. Mestre em Educação, Arte e História da Cultura. ORCID: https://orcid.org/0000-0003-3008-6223. E-mail: lepp@rc.unesp.br

${ }^{3}$ Universidade Presbiteriana Mackenzie (MACKENZIE), São Paulo - SP - Brasil. Professora Pesquisadora. Doutorado em História (PUC). ORCID: https://orcid.org/0000-0003-3734-0941. E-mail: rosanamaria.schwartz@mackenzie.br

${ }^{4}$ Universidade Estadual do Ceará (UECE), Fortaleza - CE - Brasil. Docente no Programa de Pós-Graduação em Políticas Públicas (Orientador de Mestrado e Doutorado). Doutorado em Educação Escolar (UNESP). PósDoutorando em Direitos Humanos e Cidadania (UnB). ORCID: https://orcid.org/0000-0003-1171-217X. E-mail: r.silva@unesp.br
} 
ABSTRACT: Indigenous peoples have remained unique due to their social and cultural strategies, and educational activities are one of them. Education carried out by indigenous peoples allows them to continue to survive and prevent their culture from being passed on from generation to generation. The Tikunas have had a long trajectory over their history. From its mythological origins to their first contact with the Western civilization, it was a peaceful, stable trajectory; but has been marked with symbolic and physical violence since, resulting in the loss or the denial of certain identity traits of the people. Here, we will study the consequences of such contact.

KEY-WORDS: Contact. Ticuna. Non-indigenous. Worldview. Violence.

\section{Introdução}

Escrever sobre uma história que não foi privilegiada pela historiografia até os anos de 1990 é desafiador e instigante, principalmente quando se faz parte dela. Como Ticuna, sempre me inquietou estudar as consequências do processo civilizatório, implementado desde o início da conquista das Américas pelos portugueses, na contemporaneidade, pois a violência, a degradação e os desenraizamentos e destribalização marcam a história, a cultura e a educação indígena Ticuna.

A historiografia não-indígena pontua que, por volta de 1500, existiam de 1 milhão a 3 milhões de indígenas no Brasil (FUNAI) ${ }^{5}$ e que em cinco séculos, essa população nativa reduziu-se a 306 mil, o que representa $0,03 \%$ da população brasileira, segundo o IBGE (2010).

A história de um povo tem um valor decisivo na vida dos sujeitos, seja para planejar o futuro cheio de conquistas ou, simplesmente, para se acomodar diante das mais diversas situações, por desconhecer a história. Desta forma, o objetivo deste artigo é tentar percorrer os caminhos da história dos povos originários, e, em especial, do povo Ticuna, com um enfoque especial na educação. Iniciando pelas origens mitológicas dos Ticuna, seguimos pela destruição dos pilares da sua organização social com a chegada do não-indígena, o movimento indígena, suas lutas e conquistas; chegando, por fim, a uma ressignificação conseguida por este povo hoje.

${ }^{5}$ Pierre Clastres aponta para uma estimativa mais elevada: cerca de 25 milhões de índios habitavam, segundo o autor, a América do Sul, 100 milhões no continente americano como um todo; e que, cerca de cem anos após o início do processo de colonização, um quarto da população mundial havia sido dizimado; constituindo uma das maiores tragédias da humanidade (CLASTRES, 2012, p. 114).

Rev. Sem Aspas, Araraquara, v. 10, e021006, jan./dez. $2021 . \quad$ e-ISSN 2358-4238 


\section{Localização}

Atualmente, as aldeias do povo Ticuna estão localizadas na região do Alto Solimões, no estado do Amazonas, à beira do rio Solimões e cabeceiras dos pequenos rios.

Antes do contato com os brancos, não haviam aldeias: eram famílias clânicas que moravam uma bem distante da outra. As primeiras aldeias vão surgir com a presença de novos agentes procedentes de fora, no início do século XX, com a presença do Serviço de Proteção ao Índio-SPI; A primeira de que se tem notícia foi a aldeia de Umariaçú. Outro agente responsável por ajuntar famílias Ticunas foi o protestantismo: foi o caso do município de Santa Rita do Weil, que cedeu terras para as famílias adeptos à religião deram origem à Comunidade de Campo Alegre; e do município de Santo Antonio do Iça, de onde surgiu a comunidade Vila Betânia.

Figura 1 - Localização do povo Ticuna

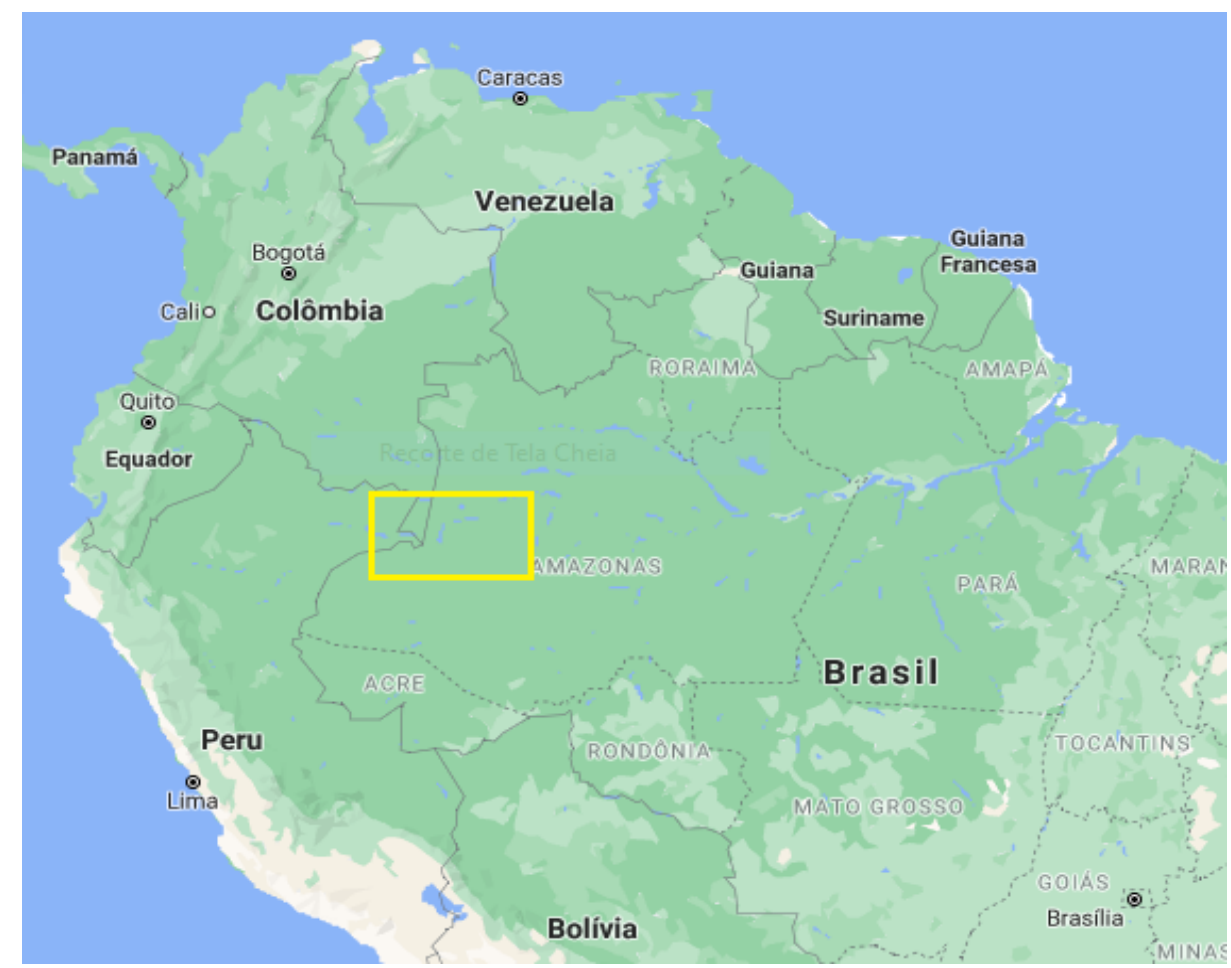

Fonte: Google (2020)

As aldeias, hoje são em número de 250 , encontram-se situadas em territórios de 7 municípios: Tabatinga, Benjamin Constant, São Paulo de Olivença, Amaturá, Santo Antônio de Içá, Tonantins e Coari. Nos últimos 25 anos, algumas famílias migraram do Alto Solimões a distâncias de mais de $1.000 \mathrm{~km}$, descendo o rio Solimões até à cidade de Manaus, onde atualmente há uma aldeia urbana no bairro Cidade de Deus. 
Pelo fato de sua localização ser a tríplice fronteira, também há aldeias do povo Ticuna nos países vizinhos do Peru e da Colômbia. A relação de comunicação e intercâmbio com as aldeias dos três países é constante, pois para o indivíduo Ticuna, a barreira das fronteiras é um fator de menor relevância a dividir o povo: os fatores que os unificam, como a identidade cultural e linguística, são maiores.

Trata-se de um povo milenar, que já habitava a Bacia Amazônica há pelo menos 2 mil anos antes da chegada dos colonizadores portugueses e espanhóis, ocupavam as terras firmes e principalmente as cabeceiras dos pequenos rios/igarapés, afluentes do rio Solimões. Segundo Silva (2014, p. 24) “de acordo com registros arqueológicos, os Tikuna datam de 950 $( \pm 90)$ d. C. com base em fragmentos cerâmicos semelhantes a cerâmicas feitas pelos Tikuna atuais."

\section{Gênese do povo Ticuna na perspectiva mitológica}

Normalmente a pergunta a ser feita por um não-indígena seria: "a qual o país pertence os Ticunas? Será que são brasileiros, peruanos ou colombianos?". Como a perspectiva que este artigo busca é identitária, ou seja, como os Ticuna percebem-se a si mesmos, a resposta a esta questão vem, inevitavelmente, através dos mitos contados de geração para geração.

Neste capítulo, introduziremos a história da criação do mundo da perspectiva dos Ticuna, com dados coletados a partir de relatos dos anciões ${ }^{6}$, reorganizados por mim.

Os anciões contam que, antes do mundo existir, Ngutapa, o Deus da criação, já existia, não tendo pai ou mãe. Casou-se com Mapana, com quem desejava muito ter um filho. Contudo, a esposa não lograva engravidar, e Ngutapa ficou irado: convidou-a para adentrar a mata, onde planejava abandoná-la como castigo.

Da maloca onde moravam, seguiram por uma trilha, e, depois de caminhar bastante, ele sentou-se sobre o tronco de um pau caído à beira da trilha, chamou sua mulher e questionou: "Por que você não me deu um filho, me diga qual é o motivo?” Ela respondeu: “É por isso que você está irado?”. Ele confirmou e partiu para cima dela, agredindo-a. Indefesa, ela chorou em voz alta, pedindo socorro, mas ninguém estava por perto para lhe ajudar.

Ngutapa a espancou mais forte, batendo com força no seu peito: Mapana caiu no chão semimorta. Ele pegou uma corda de cipó e amarrou seus pés e braços junto ao tronco de uma árvore e foi embora, abandonando-a mata adentro, bem longe de sua casa.

${ }^{6}$ Dados coletados na Comunidade de Filadélfia, Terra Demarcada de Santo Antônio, município de Benjamin Constant-AM, durante o ano de 2019. 
Mapana ficou abandonada à própria sorte, presa por uma corda de cipó junto ao tronco, sem chance de libertar-se. Chorou com voz alarmante, e foi nesse momento que um pássaro chamado Coü aproximou-se e ficou cantando ao seu redor. Desesperada por ajuda, pediu: "Pássaro Coü, que bom que você ouviu meus gritos por socorro, venha me ajudar, esse maldito Ngutapa castigou-me". O pássaro desceu da árvore e perguntou: "É você minha neta $^{7}$ ? O que houve contigo?"

Naquele momento, o pássaro Coü transformou-se num belo índio Ticuna. Cheio de compaixão pela mulher Mapana, que estava quase morrendo, aproximou-se dela, lhe perguntando novamente: “Que houve com você, minha neta?” Ela respondeu: "Ngutapa não vale nada, me castigou! Por favor, me desamarre deste tronco! Já estou exausta, não suporto mais a dor".

Coü cuidadosamente soltou as cordas dos braços e dos pés, deixando-a totalmente livre, depois orientou-a a retribuir o castigo para Ngutapa: "Você vai apanhar um ninho cheio de marimbondos e vai aguardar Ngutapa passar pelo caminho. Mas você deve se esconder no meio do mato de tal forma que ele não te veja ao passar por perto da armadilha. Deves jogar na altura de seus joelhos o ninho de marimbondos. Combinado?" Ela concordou, e seguiu para executar sua vingança.

Mapana foi à procura do ninho de marimbondos, e logo encontrou um. Com uma folha na mão, aproximou-se, pegou o ninho e cuidadosamente o carregou pela trilha.

Caminhando devagar, aproximou-se do local por onde Ngutapa geralmente passava: naquele dia, ele viria tocando uma música e dançando, para comemorar o castigo bemsucedido de sua mulher.

Mapana, ao chegar na trilha, procurou um lugar com bastante mato, onde se escondeu. Discretamente, aguardou o momento em que seu marido iria passar. Não demorou muito, lá vinha Ngutapa, cantando e dançando. Quando passou bem pertinho, ela então jogou sobre ele o ninho do marimbondo, bem na direção dos joelhos.

Os marimbondos ferraram os dois joelhos: a dor foi insuportável, e Ngutapa não conseguia caminhar. Aos gritos, pedia por perdão para sua mulher, e saiu se arrastando em direção à sua maloca, mal tendo forças para conseguir se deitar na rede, assim que conseguiu chegar.

Depois de uma semana de muito sofrimento e dor, seus joelhos incharam muito. O tamanho era grande demais, e ele quis saber o que havia de errado. De repente, percebeu que 
dentro de cada joelho havia pessoas diferentes: no joelho direito, estava sendo gerado Yo'i, que estava confeccionando uma zarabatana; e sua irmã Aicüna, muito ocupada tecendo uma rede. No joelho esquerdo, estava Ipi, trabalhando com a confecção de um arco e uma flecha. Do seu lado, estava sua irmã Mowatcha, também ocupada tecendo uma bolsa de fibra de tucum.

Então, foram dos joelhos de Ngutapa que vieram à existência Yo'i, o deus bom, e Ipi, o deus do mal. Estes personagens são importantes para a criação dos índios Ticuna, pois, de acordo com a memória dos mais velhos da comunidade, transmitida oralmente de pais para filhos, este povo é denominado como povo Magüta, termo da língua Ticuna que significa "gente de verdade", nome dado no momento da criação pelo herói mítico Yo'i, o Deus bom.

Yo'i, o Deus Ticuna, tinha o poder de tornar real tudo o que pensava ou desejava. Enchia a Terra com vida e esperança, mas se sentia solitário, porque vivia só com seus irmãos. Yo’i e Ipi decidiram derrubar essa árvore e trazer luz ao mundo, convidando todos os animais da floresta para ajudar. Mas nem o pica-pau conseguiu. Só conseguiu o Quatipuru Taine, pois prometeram-lhe como recompensa o casamento com Aicüna. Ele subiu até o topo da árvore e descobriu que uma preguiça segurava a árvore no céu. Taine jogou formigas de fogo nos olhos da preguiça, e a preguiça soltou o céu. Com isso, a árvore caiu, mas o tronco se regenerava muito rápido, pois a árvore tinha um coração. Ipi tentou tirá-lo com um machado, mas o coração pulou bem longe: foi uma borboleta que conseguiu pegar ele no meio do pulo. Ela passou para o calango, e ele passou para a cutia, que saiu correndo e o plantou, escondido dos irmãos Yo’i e Ipi. Mas Yo'i procurou e encontrou o coração-caroçosemente, levando-o para plantar no seu terreno. Com o tempo, nasceu a árvore de umari, e sua última fruta deu origem à mulher de Yo'i, que depois teve um filho de Ipi. Yo'i chamou Ipi e seu filho, para purificá-lo pintando seu corpo com jenipapo. Yo’i mandou Ipi ralar o jenipapo sem parar, mas com isso ele acabou ralando o seu corpo junto, e a carne de Ipi misturou-se com a borra do jenipapo. A mistura de sangue, carne e sementes foi lançada ao rio Eware por sua esposa Tetchi arü Ngu'i, transformando-se em peixes. Ela ficou triste por ter jogado ele no rio, e pediu para Yo’i pescá-lo de volta. Yo’i, cansado de ficar sozinho e desejando povoar a Terra e deixar o mundo mais alegre e completo, pescou os peixes do rio, um por um. Mas vieram com o anzol somente animais, sempre junto macho e fêmea: foram assim que surgiram os animais. Mas Tetchi arü Ngu'i queria seu esposo, e Yo'i queria seres humanos: como pescá-los? Decidiu trocar a isca por macaxeira: assim, tudo que ele pescava passou a se transformar em seres semelhantes a ele, humanos, que saiam correndo pela terra. Foi assim que surgiu a humanidade, e foi assim que surgiu o povo Magüta. Dentre a piracema, ele viu 
um peixe diferente, de testa dourada, mas o peixe não mordia a isca. Teve uma ideia, e pediu que Tetchi arü Ngu'i tentasse pescar, pois achava que o peixe era Ipi. Acertou: o peixe pulou fora da água e se transformou em Ipi. Ipi viu o que o irmão fez, e quis um povo para ele também. Com isso, pescou outras pessoas com macaxeira, mas afilou o nariz de cada um, para diferenciar do povo do irmão: assim nasceram os peruanos, e seguiu com eles em direção à nascente do sol. Mas Yo'i quis confundir o irmão, e virou o mundo ao contrário, fazendo Ipi ir para o sol poente, onde havia muito ouro. Lá, Ipi ficou controlando as águas do Amazonas, controlando para que não fosse muita nem pouca a vazante. Yo’i deixou o povo Magüta na terra sagrada de Eware e foi para o sol nascente, na esperança de trazer ferramentas para a agricultura do seu povo.

Contam que estando à beira do lago Eware, o lago sagrado, Yo'i pegou seu caniço (a vara de pescar) e usou como isca uma semente de coquinho (um caroço de tucumã, que, por sua vez, é uma espécie de palmeira) para tentar pescar. Logo jogou o anzol na água e, ao puxá-lo, o peixe fisgado transformou-se em porco do mato. Lançou o anzol novamente, e surgiu outro animal, e assim por diante, até todos os animais surgirem, cada um com seu par macho e fêmea. Como o porco do mato foi o primeiro a morder o duro coquinho, até hoje seus dentes são duros e resistentes.

Ao perceber que o peixe fisgado não se transformava em gente, Yo'i decidiu trocar de isca: foi à roça em busca de macaxeira, e assim que conseguiu alguma a colocou no anzol: os peixes que foram fisgados transformaram-se em duuû́'gü (gente de verdade) e estes foram os Ticunas “o povo Magüta”. Este é o motivo pela qual os dentes dos Ticunas são moles e não muito resistentes.

Como o povo Ticuna, sob perspectiva mitológica, originou-se na terra sagrada de Ewaré, hoje próxima à Comunidade de Vendaval, município de São Paulo de Olivença, oficialmente, os Ticuna tem origem brasileira. Contudo, vale dizer que, na verdade, eles não percebem sua identidade como pertencente a qualquer um dos três países, mas sim a uma Nação Ticuna, que engloba o território onde habitam.

Voltemos, porém, às narrativas mitológicas.

O avô do professor indígena Santos Cruz conta que depois de Yo'i haver pescado as pessoas, chegou a hora em que todas as pessoas precisavam tomar um banho no lago sagrado Eware, para isso as pessoas foram divididas em três grupos. O primeiro grupo que tomou banho ficou bem limpo, bem branco: estas são as pessoas que hoje possuem pele bem branca, como os alemães, francês, italianos etc. O segundo grupo foi tomar banho na mesma água, mas como a água estava um pouco suja com a sujeira do primeiro grupo, a pele não ficou bem 
limpa: estes ficaram com a pele morena, são os Ticuna. Por último fizeram uso da mesma água para tomar banho o terceiro grupo, aí a água já estava muito suja, não sendo possível a limpeza da pele: por isso, as pessoas do terceiro grupo ficaram com a pele bastante negra.

Percebamos, porém, como esta última narrativa já possui, na verdade, a marca do contato com o não-indígena; tentando incluí-lo na cosmogonia indígena. Contudo, infelizmente, também penetrou nesse mito a noção errônea de que há "níveis de limpeza" para a população, propagando assim, subrepticiamente, a ideia de que um povo seria superior ao outro. Perceba como esta narrativa evidencia a penetração da violência simbólica nãoindígena na cultura Ticuna, pois mostra a superioridade de um outro povo, o europeu, sobre os Ticuna, em sua própria narrativa cosmogônica.

Segundo os velhos da tribo os contadores da história, esta parte da história não é contada para as pessoas do primeiro grupo e do terceiro grupo.

Gruber, que trabalhou na confecção de um livro que versa acerca de árvores, juntamente com os professores Ticunas, afirma, a respeito do mito da criação:

Quando a piracema passou, Yo'i fez um caniço e foi pescar, usando caroço de tucumã maduro. Mas os peixes, quando caíam na terra, viravam animais: queixada, anta, veado, caititu e muitos outros. Aí Yo'i usou isca de macaxeira, e com essa isca os peixinhos se transformavam em gente. Yo'i aproveitou e pescou muita gente. Mas seu irmão não estava entre essas pessoas. Yo'i então, entregou o caniço para Tetchi arü Ngu'i e ela conseguiu fisgar um peixinho que tinha uma mancha de ouro na testa. Era Ipi. Ipi saltou em terra, pegou caniço e pescou os peruanos e outros povos. Esse pessoal foi embora com Ipi para o lado onde o sol se põe. Da gente pescada por Yo'i descendem os Ticuna e também outros povos que rumaram para o lado onde o sol nasce, inclusive os brancos e os negros (GRUBER, 1997, p. 18).

O povo Ticuna, ou povo Magüta, conforme afirmação dos velhos da tribo, significa gente de verdade, criados e dotados de inteligência para cuidar de sua sociedade, portanto organizados politicamente, economicamente, socialmente e culturalmente.

Com relação à organização social, segundo as histórias, quando ainda eram contadas oralmente pelos anciãos da aldeia, afirmam que foi estabelecido por "Yoi" o sistema regulador da sociedade Ticuna que consiste em atribuir uma identidade familiar em base ao clã, que são famílias extensas e que tem como função legitimar o casamento, impedindo a união com membro da mesma família, evitando assim o incesto.

Todos os povos têm formas de se organizarem para evitar problemas e viver em harmonia. Para a origem dos clãs, que resolveu o problema do casamento consanguíneo, temos duas histórias diferentes. PRIMEIRA: Depois de pescados, o povo Ticuna se dividiu em pares e ficavam dispersos, mas tudo acontecia de bom e de ruim. Yo'i decidiu organizar 
seu povo e dividi-lo em clãs: procurou uma jacarerana (ngiri), cortaram e cozinharam, dando para todos comerem. O primeiro a provar o caldo sentiu gosto de sangue (naiãca), e pegou o clã de onça, o segundo sentiu gosto de óleo e pegou o clã de mutum, o terceiro gosto de madeira estragada (nguaca) e pegou o clã de avai, e assim por diante; se dividindo em dois grupos: "com penas" e "sem penas". SEGUNDA: Conta-se que os Ticuna praticavam antropofagia de época em época com alguém. Nesse pensamento eles observavam se alguém no meio se engordava demasiadamente: o Ticuna tinha concepção que a pessoa saudável possui espírito forte. Ao praticar o ritual, acreditavam que o espírito era transferido para as pessoas envolvidas na festa. Certo dia, planejaram uma festa de ritual de antropofagia onde secretamente alguém era indicado para ser elemento do ritual. Era o pupunary (pássaro), porém o pupunary ficou desconfiado quando o dia da festa chegou e fez uma máscara para observar mais a situação. O que ele ouviu da boca dos anfitriões da festa era que a festa não começava pois faltava o pupunary. Ao ouvir isso, o pupunary se mandou, e fugiu para bem longe do grupo, se transformando em pássaro. Foi buscar o jacurana e jogou na cumeeira da casa, depois fugiu. Já que não mais apareceu na festa o esperado. Os ritualistas aproveitaram o jacurana para o almoço, e quando cada um foi provar, sentiu os sabores de determinadas aves, animais ou árvores. A partir disso que surgiram os clãs na etnia Ticuna. Desde então, cada grupo clânico não pode mais comer o animal a que pertencia, porque se entendia que faz parte do seu corpo.

Os Ticuna ainda possuem uma série de outras histórias que dão conta de explicar seus costumes, suas tradições, bem como questões existenciais como "de onde viemos?", "para onde vamos?”, “o que fazemos aqui?”, etc. Tais histórias, transmitidas oralmente de geração em geração, contribuem para que o povo Ticuna consiga afirmar positivamente sua identidade no ambiente em que ocupa e, além disso, para que mantenha uma estabilidade com relação ao passado. Com isso, ocorre um fenômeno descrito por Clastres (2012): o indígena não é um povo sem história, mas sim um povo que opta por uma sociedade onde mudanças sociais não são desejáveis por seus membros, de forma que a história do povo Ticuna, em certa medida, não possuiu episódios de grande vulto entre a sua criação mitológica e a chegada dos europeus.

Contudo, para o escopo deste artigo, preferimos nos ater aos mitos já elucidados acima, pois consideramos que a visão Ticuna já se encontra bem exemplificada com eles, bem como alguns aspectos essenciais de sua identidade (como a origem da divisão clânica).

Mesmo que abordemos uma perspectiva científica para a origem dos Ticuna, que não seria o escopo deste artigo, pois foge ao tema de como os Ticuna percebem sua própria 
identidade, perceberíamos que, mesmo após a chegada dos indígenas na região sul-americana, ocorreram poucas mudanças: mesmo a passagem pela Revolução Agrícola não lhes despertou o desejo por um poder centralizador, pela acumulação de bens, pela criação de um Estado. A sociedade indígena permaneceu, portanto, contra tal Estado, conforme narrado por Clastres.

O desejo de acumulação individual, de progresso do um e não do todo, existe em pequena medida, mas há mitos que dão conta de mostrar ao povo a importância de que, havendo progresso ou mudanças, elas venham para o todo, e não para o indivíduo. A feitiçaria Ticuna, por exemplo, conforme narrado por Vasques (2014), é um mecanismo social ainda presente: quem tenta acumular, vira alvo de pedidos de favores por parte de seus vizinhos, e, se tenta negá-los, vira alvo de feiticeiros.

Uma vez que já observamos como o sistema Ticuna deu conta de manter-se estável ao longo dos séculos, observemos agora como o processo de eliminação identitária não-indígena afetou profundamente a estrutura social das comunidades.

\section{A destruição dos pilares da sociedade Ticuna}

A partir desta seção, acompanharemos o relato de alguns pesquisadores e viajantes. Primeiramente, Silva apresenta uma breve justificativa sobre o uso de relatos de viajantes para reconstruir a história dos povos indígenas.

Os relatos destes viajantes, apesar de meramente descritivos, servem de base, inclusive, para conhecimento da forma de vida desta etnia como descrição física, comportamento, organização social, traços da personalidade, costumes, mitos e cosmogonia e registram também sua localização geográfica desde o Rio Napo (no Peru) até o Alto Amazonas (atual Rio Solimões) no Brasil (SILVA. 2014, p. 24).

Clastres (2012), inclusive, valoriza o relato de viajantes em seus trabalhos, pois estão entre únicos documentos que possuímos sobre os indígenas no período colonial, especialmente se considerarmos os primeiros séculos de contato. Os povos indígenas, infelizmente, por ainda naquela época não dominarem a língua escrita, ainda não conseguem dispor de meios de contrapor sua história à história dos brancos.

Antes das atuais delimitações dos países, de caráter geopolítico, originalmente o território tradicional Ticuna era um só: a cabeceira dos pequenos rios, onde os Ticunas habitavam em suas malocas clânicas. Com o passar dos anos, com a suposta extinção do povo Kambeba e domesticação do povo Cocama pelos colonizadores, os Ticunas desceram das 
cabeceiras dos pequenos rios, para tentar habitar junto à beira do rio Solimões, onde permaneceram.

Já na primeira metade do século XIX, na região do Alto Solimões, alguns povos já estavam extintos ou assimilados pela cultura europeia. De acordo com Bates (1973, p. 175), citado por Oliveira (2015, p. 59):

Por volta da primeira metade do século XIX os viajantes que passavam pelo Alto Solimões traçam o seguinte panorama: o índios do Iça estão praticamente extintos (passes, juris, yumanas e mariates), exceto umas poucas dezenas vivendo juntos aos não índios, principalmente em Tonantins dos omáguas não existe mais qualquer referência $[\ldots]$

Os Kambebas ou Omáguas eram habitantes da beira do rio Solimões, por isso foram os primeiros a ter contato com o homem branco, sofrendo os maiores impactos da colonização. Foram tidos como povo extinto, mas, nos últimos dez anos, remanescentes deste povo que por muitos anos permaneceram no silêncio, estão ressurgindo e se afirmando como povo.

Os europeus que por aqui chegaram estabeleceram um sistema de controle eurocêntrico que por cinco séculos sufocou a cultura indígena. Como consequência, muitos povos tiveram que negar sua identidade, como uma forma de garantia da sobrevivência. Outros se afastaram para lugares de difícil acesso, fugindo do terror protagonizado pela frente de contato dos colonos bandeirantes e extrativistas e tentando, desta forma, manter o seu meio de vida.

Oliveira Filho (1988, p. 31) afirma que “A preocupação dominante era mostrar a progressiva descaracterização cultural daquelas sociedades e a absorção de crenças e costumes procedentes do branco". Em outras palavras, absorvidos pela cultura dominante e dominadora, os índios foram obrigados a abandonar seu próprio sistema de organização social e aceitar o modo de vista imposto.

Como consequência da imposição da cultura eurocêntrica, lamentavelmente percebemos muitos dos remanescentes Ticuna que desconhecem os saberes tradicionais, pois, nas famílias e no cotidiano, grande parte da cultura deixou de ser socializada.

Abordaremos, a seguir, dois dos aspectos mais facilmente verificáveis que se perderam entre a cultura Ticuna. 


\section{As malocas clânicas}

A moradia original onde os Ticunas habitavam, antes da presença dos colonizadores na região, até final do século XVIII, era a maloca clânica, projetada para abrigar todos os membros de uma extensa família clânica. A estrutura era construída de madeiras de árvores bem selecionadas, de forma a apresentar longa durabilidade.

A mobilidade dos assentamentos Tikuna interferiu na estrutura da moradia, que, durante a exploração hispano-lusitana ainda era a maloca. Construída para abrigar avós, pais, filhos, genros, noras e netos; apresentava no século XIX, de acordo com Marcoy (2001) formato arredondado, descrita de forma mais detalhada por Bates (1857, p. 292-294) em sua viagem a São Paulo de Olivença: '[...] uma ampla choupana de formato ablongo, cuja parte interna era arranjada de forma desordenada e assimétrica que dava a impressão de ter sido construída por vários pedreiros que trabalhassem independentemente e fossem colocando vigas, esteios, etc., sem tomar conhecimento do que os outros vão fazendo. As paredes e o teto eram cobertos com um trançado de folhas de palmeira. Redes penduradas entre grossos mourões que sustentavam o teto deixavam uma passagem livre no centro, onde era acendido o fogo; num dos lados erguia-se um jirau feito de troncos de palmeira partidos ao meio de sentido longitudinal (SILVA, 2014, p. 44).

Antes de construir a maloca, a arquitetura era muito bem pensada e planejada, de forma a atender as demandas de todas as necessidades da extensa família, tais como conforto e segurança. Acima de tudo, deveria estar bem protegida contra animais perigosos da selva, que poderiam invadir a parte interna da moradia, como serpentes, onças, pernilongos e outros insetos porventura letais.

O formato da maloca era em estilo oval, coberto desde o chão até o teto com um tipo de palmeira nobre conhecido como caraná, retirada do mato com a ajuda de todos os habitantes da moradia. No primeiro dia, com a ajuda de todos, as palmeiras são cortadas e amarradas em feixes de até $80 \mathrm{~kg}$, de forma a facilitar o transporte. Para a cobertura da maloca, eram necessários de 15 a 20 feixes, que eram transportados até o local da construção, onde eram tecidas, costuradas numa vara no formato de um pente. Já transformadas no formato de um pente, eram agrupadas para dar forma à maloca: para a cobertura e a parede, eram necessários de 200 a 300 pentes, feitos de palha de caraná.

Na década de 20, quando o etnólogo alemão Curt Nimuendaju visita pela primeira vez a região do Alto Solimões, verifica que a cultura da maloca já estava extinta. A partir da memória dos remanescentes Ticuna com a qual teve contato, tece algumas considerações a respeito do assunto. 
Nimuendajú (1952), citado por Silva, S. (2014, p. 44), “[...] retrata por intermédio de testemunhos orais, o desenho da maloca Tikuna, em formato 'aparentemente' circular com uma secção retangular de formato quadrangular, de um, dois ou três metros."

O tipo de moradia dos Ticunas, as ocas clânicas, foram um dos pilares que foram destruídos e extintos pelos colonizadores que por aqui chegaram, mais conhecidos popularmente como os "patrões" ou "coronéis do barranco". Eles obrigaram os Ticunas a abandonar a maloca, pois julgavam que pelo fato de viverem em grande número de pessoas na mesma casa eram preguiçosos, além de serem um eventual risco, no caso da organização de uma rebelião.

Visto que o maior interesse dos "patrões" era a produção em grande escala dos produtos do extrativismo, uma vez sob o domínio dos colonizadores os indígenas foram obrigados a viver e trabalhar forçadamente, atendendo aos interesses do "patrão". Além de passarem em residir em casas que refletiam os núcleos familiares, em modelos similares aos dos "patrões", uma outra mudança importante ocorreu: não podendo mais apenas produzir para si mesmos em um modelo de vida autossustentável, foram obrigados a deixar de ser autônomos e a servir ao interesse de outrem.

A respeito do abandono das malocas clânicas e do fim do modelo de vida autossustentável pelos Ticunas, Silva (2014, p. 78), também afirma: “De acordo com Cardoso de Oliveira (1964:54); Umbarila (2003); Garcés (2000) o sistema de endividamento para exploração do látex ao qual foram submetidos os indígenas, promoveu aos Tikuna do Brasil e da Colômbia o abandono de suas malocas".

\section{A liderança}

Documentos a respeito do povo Ticuna antes do contato com o não-indígena são escassos. Com relação a essa realidade Nimuendajú (1952, p. 116), citado por Oliveira (2015, p. 48) afirma:

Os dados sobre a "situação pré-contato" são bastante escassos e caracterizam-se pelo caráter conjectural e fragmentário. O pouco que se pode dizer com relativa segurança é que os ticuna, antes da chegada dos portugueses e espanhóis na região, foram índios da terra firme, habitando os altos igarapés situados à margem esquerda do rio Solimões, no trecho atualmente compreendido entre Tabatinga e São Paulo de Olivença. Desconheciam de canoas e ubas, evitando sistematicamente as beiras do Solimões, ocupado pelos Omaguas, inimigo dos ticuna e que em alguns de seus mitos e lendas aparecem realizando incursões contra a suas malocas (NIEMUENDAJÚ, 1952, p. 116). 
No entanto, as histórias contadas e passadas de geração em geração salientam que os ticunas, antes de sofrerem a invasão territorial, gozavam de autonomia com relação à própria forma de governar, sendo que cada oca clânica tinha seu próprio líder, mais conhecido como (To'ü eru), cuja habilidade era comparada com a esperteza do macaco (To'ü).

O líder nato, desde sua infância, era separado e treinado pelo líder-mestre em todos os saberes da tribo para se construir enquanto tal. Isso incluía a abstinência de certos alimentos e da prática do sexo fora do tempo permitido, pois, deveria ter total compromisso com os interesses do povo e não desperdiçar seu tempo em outros assuntos. Era, portanto, conforme afirma Clastres (2012), uma figura que emana do povo, um verdadeiro democrata numa sociedade onde não se admite um poder centralizador: uma sociedade contra o Estado.

Este líder deveria apresentar habilidade para preparar o povo para as guerras que constantemente aconteciam entre povos vizinhos. Era papel dele também empreender a confecção de zarabatanas, arcos e flechas usados nas atividades da caça de animais e também nas guerras.

Com a chegada dos colonizadores, a figura do líder nato foi extinta, sendo substituído pelo líder e patrão não-indígena. Posteriormente, esta figura foi substituída, ainda, pelo capataz e pelo capitão, líderes que não representavam mais o interesse do povo, e sim do dominador patrão não-indígena.

Ao longo dos anos, produziu-se o hibridismo ${ }^{8}$ e a gestação da dependência da cultura hegemônica europeia dominante.

Isso gerou sérias consequências de ordem psicológicas e sociais.

Dois fatores vão se conjugar para dar ao seringueiro-índio a sensação de abandono e de deterioração de sua condição de vida, fato que os informantes ticunas algumas vezes atribuem à sucessão de direção no âmbito da empresa, outros vindo substituir os "bons patrões" de antigamente (OLIVEIRA, 2015, p. 75).

Uma vez extinto o líder genuíno, os Ticunas espalharam-se para qualquer direção, seguindo qualquer pessoa. Um exemplo muito lembrado por alguns Ticuna é o do bando de porcos, quando seu principal líder é morto pelo caçador.

O legado da hegemonia hispano-lusitana foi a dependência crônica dos índios em algum líder, ao aceitar a posição de inferioridade com relação aos não-indígenas.

${ }^{8}$ Do contato de uma cultura com a outra nasce uma terceira. 


\section{Considerações finais}

Todo o processo de colonização do povo Ticuna, desde a chegada do não-indígena, foi inevitavelmente permeado pelo pensamento europeu, especialmente aquele advindo da Era Industrial' responsável pela extinção e silêncio da diversidade de culturas indígenas.

O tipo de estrutura social próprio da era industrial conduz, ao contrário, grandes massas de população, pertencentes às culturas inferiores descontínuas, em direção às altas culturas normalizadas, homogêneas, secularizadas, transmitidas não somente pelas elites, mas por instituições educativas especializadas sustentadas pelo poder central (POUTIGNAT; FENART; BARTH, 1988, p. 47).

Também de acordo com Luciano (2006, p. 41), “O objetivo, portanto, não era tanto cultural ou racial, mas, sobretudo econômico, guiando toda a política e as práticas adotadas pelos colonizadores". Assim, as caravanas procedentes de Portugal chegaram à terra que era habitada pelas diferentes nações indígenas, motivadas pelo acúmulo de riquezas, desconsiderando a autonomia, o tipo de vida social, político, religioso e a economia dos povos indígenas.

Ao aportar na terra já habitada pelos índios, a caravana dos homens não-indígenas observou a abundante riqueza natural existente, que no imaginário deles não era de propriedade de ninguém, e imaginou a facilidade de se apossar das mesmas.

$\mathrm{Na}$ tentativa de explorar a riqueza encontrada, perceberam que não fora possível extrair a riqueza em grande quantidade com a mão-de-obra dos poucos homens que aqui aportaram, pois o trabalho era difícil e braçal: a alternativa encontrada para acelerar o trabalho de exploração era de incluir a mão-de-obra indígena, e, posteriormente, a mão-de-obra negra, contra a vontade de tais povos.

No momento do encontro com os visitantes estrangeiros que aqui chegaram, a intenção dos indígenas era de prover a melhor recepção, oferecendo ajuda em hospedagem, proteção, alimentação e até mesmo dando presentes como bens preciosos, atitudes que tinham como principal objetivo conhecer melhor o outro, a fim de construir bons relacionamentos, como donos de casa.

Tais atitudes provam que os povos originários ou natos desta terra eram sociedades autônomas muito bem governadas e economicamente autossuficientes; no entanto, a intenção dos visitantes europeus era de explorar a riqueza encontrada e consequentemente de subjugar o índio ao trabalho escravo, para promover seus próprios interesses. Assim, o encontro foi desigual e paulatinamente destruidor da sociedade indígena, tendo como seus principais 
símbolos a perda da maloca clânica e a sua substituição por casas; e a perda do líder tradicional, sendo ele substituído por “patrões”, capatazes destes patrões, pelo poder público, e, mais recentemente, pelos caciques, líderes eleitos.

Com a conquista de alguns marcos legais e de terras, os povos Ticuna, destituídos de parte de sua identidade, lutam para tentar manter o que lhes resta.

\section{REFERÊNCIAS}

BARBERO, E. P. Artes Indígenas no Brasil-trajetórias de contato. 2010. Dissertação (Mestrado em Educação, Arte e História da Cultura) - Universidade Presbiteriana Mackenzie, São Paulo, 2010.

BOAS, F. Antropologia cultural. Rio de Janeiro: Zahar, 2005.

CLASTRES, P. A sociedade contra o estado: pesquisas de antropologia política. São Paulo: Cosac Naify Portátil, 2012.

ELIAS, N. O processo civilizador: uma história dos costumes. Rio de Janeiro: Zahar, 1990. V. 1.

FERNANDES, F. A investigação etnologica no Brasil e outros ensaios. Petrópolis: Vozes, 1975.

FREIRE, J. R. Cinco idéias equivocadas sobre índio. Manaus: Cenesch, 2000.

GADOTTI, M. A escola e o professor: Paulo Freire e a paixão de ensinar. 1. ed. São Paulo: Publisher Brasil, 2007.

GEERTZ, C. Nova luz sobre a antropologia. Rio de Janeiro: Zahar, 2001.

GEERTZ, C. O saber local: novos ensaios em antropologia interpretativa. Petrópolis: Vozes, 2003.

GENNEP, A. V. Ritos de passagem. Petrópolis: Vozes, 2013.

GRUBER, G. J. (org.). O livro das árvores. Organização Geral dos Professores Ticuna Bilíngues, 1997.

LEVI, G. Usos da Biografia. In: AMADO, J. Usos e abusos da história oral. Rio de Janeiro: Fundação Getúlio Vargas, 1996.

LUCIANO, S. G. O índio brasileiro: o que você precisa saber sobre os povos indígenas no Brasil de hoje. Brasília: Ministério da Educação, LACED/Museu nacional, 2006.

MACEDO, G. M. A conversão cristã e identidade ticuna: a trajetória de Campo Alegre. Amazonia em Cadernos, Manaus, n. 5, p. 175-193, jan./dez. 1999. 
MAGÜTA. A lágrima Ticuna é uma só. Benjamin Constant AM, 1988. (Centro de Documentação e Pesquisa do Alto Solimões)

MALINOWSKY, B. Coleção grandes cientistas sociais: Malinowski - antropologia. Ática, 1986.

MASINI, E. F. S.; MOREIRA, M. A. Aprendizagem significativa na escola. 1. ed. Curitiba: CRV, 2017.

MAUSS, M. Sociologia e antropologia. São Paulo: EPU: Edusp, 1974. v. 1.

NIMUENDAJÚ, C. U. Os índios Tukuna. Dados fornecidos à Inspetoria do SPI no Amazonas e Acre. Arquivo da Inspetoria, Manaus, 1929.

OLIVEIRA, J. P. Regime tutelar e faccionalismo. Política e Religião em uma reserva Ticuna. Manaus: UEA edições, 2015.

PESAVENTO, S. J. História \& história cultural. Belo Horizonte: Autêntica, 2003.

POUTIGNAT, P.; FENART, J. S.; BARTH, F. Teorias da etnicidade: Seguido de Grupos Étnicos e suas Fronteiras. Trad. Élcio Fernandes. São Paulo: Fundação da UNESP, 1998.

RIBEIRO, D. Confissões. São Paulo: Companhia da Letras, 1997.

SOARES, M. F.; PINHEIRO, P. I.; CARMO, R. O. Professores Ticunas (OGPTB). Tchorü duũũgũca' tchanu. Minha luta pelo meu povo. Niteroi RJ: EDUFF, 2014.

VERAS, P. F. M.; BRITO, G. V. Identidade étnica: a dimensão política de um processo de reconhecimento. Antropos, Anápolis, v. 5, n. 4, p. 106-124, maio 2012.

VIVEIROS DE CASTRO, E. Etnologia Brasileira. In: O que ler na Ciência Social Brasileira. São Paulo: Anpocs, 1991. v. 1.

\section{Como referenciar este artigo}

CATACHUNGA, E. L.; SCHWARTZ, R. M. P. B.; SILVA, R. A. O povo Ticuna sob uma perspectiva histórica: de suas origens mitológicas à perda de sua identidade. Rev. Sem Aspas, Araraquara, v. 10, e021006, jan./dez. 2021. e-ISSN 2358-4238. DOI: https://doi.org/10.29373/sas.v10i00.15163

Submetido em: $30 / 05 / 2021$

Aprovado em: $15 / 06 / 2021$

Publicado em: 30/06/2021 